\title{
PENDIDIKAN KARAKTER SISWA SEKOLAH DASAR MELALUI PEMBELAJARAN SENI BUDAYA
}

\author{
Hartini, Dewi Tryanasari, Endang Sri Maruti \\ Prodi PGSD Fakultas Ilmu Pendidikan IKIP PGRI Madiun \\ hartiniseniputri@gmail.com \\ dewitryyanasari@gmail.com \\ marutiendang@gmail.com
}

\begin{abstract}
The character is a distinctive personality of each individual to live and work, both in the scope of the family, community, nation and state. Arts and culture in elementary school in 2004 as a core curriculum capacity building in the field of aesthetics has a potential role to support and realize the whole Indonesian human character. This study describes the implementation and building constraints positive character of students in arts and culture in SDN Jogodayuh 1, District Geger, Madison County. This study used a qualitative research design with a phenomenological approach. Triangulation of data is done by using triangulation and triangulation methods. The results of this study indicate that many of the benefits obtained by the students in the study of art and culture in primary schools include: (1) deepen wonderfully flavors, (2) knowledge of the objective and subjective elements, (3) strengthen the love for the arts and culture, (4) foster subtlety of flavor, (5) deepen the culture, (6) assess the work of art, (7) awareness on the negative effects, (8) to strengthen public confidence, (9) discipline, and (10) provide extensive insight and provision for spiritual and psychological life.
\end{abstract}

Keywords: character education, elementary school, learning art and culture. 


\section{A. Pendahuluan}

Karakter dapat dianggap sebagai nilai-nilai perilaku manusia yang berhubungan dengan Tuhan YME, diri sendiri, sesama manusia, lingkungan, dan kebangsaan yang terwujud dalam pikiran, sikap, perasaan, perkataan, dan perbuatan berdasarkan norma hukum, agama, budaya, adat dan estetika (Samani dan Hariyanto, 2012:41). Saat ini, tindak kriminalitas, mulai dari perilaku tidak jujur, tindak kekerasan, agresivitas yang tinggi, bahkan sampai pada perilaku korup, tampaknya sangat mudah kita temui di berbagai lini kehidupan. Hal ini menunjukkan bahwa karakter positif yang seharusnya dimiliki oleh manusia sebagai fitrahnya semakin jarang ditemui.

Pendidikan memiliki peran kunci bagi kualitas peradaban suatu bangsa. Sejalan dengan pendapat tersebut, Undang-Undang Republik Indonesia nomor 20 tahun 2003 tentang Sistem Pendidikan Nasional (UU Sisdiknas) merumuskan fungsi dan tujuan pendidikan nasional yang harus digunakan dalam mengembangkan upaya pendidikan di Indonesia. Tujuan pendidikan nasional itu merupakan rumusan mengenai kualitas manusia Indonesia yang harus dikembangkan oleh setiap satuan pendidikan. Oleh karena itu, rumusan tujuan pendidikan nasional menjadi dasar dalam pengembangan pendidikan budaya dan karakter bangsa.

Seni budaya di Sekolah Dasar (SD), adalah salah satu mata pelajaran yang harus diikuti oleh siswa. Kamaril (2001) menyatakan bahwa, Mata pelajaran kesenian dalam kurikulum 2004 sebagai inti pengembangan kemampuan dibidang estetika memiliki peran potensial yang dapat mendukung dan mewujudkan kepribadian manusia Indonesia seutuhnya. Salah satu SD yang menerapkan pembelajaran seni budaya adalah SDN Jogodayuh, kecamatan Geger, Kabupaten Madiun. Dari pengamatan awal SD ini konsisten mengajarkan seni budaya sebagai salah satu mata pelajaran wajib yang harus diikuti oleh siswa namun sejauh mana pembelajaran tersebut mampu membentuk karakter positif pada siswa belum terpetakan dengan jelas akibatnya arah kebijakan sekolah terhadap pembelejaran seni budaya terkait dengan pembentukan karakter positif siswa kurang terarah. Bertitik tolak dari hal tersebut, perlu adanya pemetaan yang jelas terhadap pembelajaran seni budaya di SDN Jogodayuh, Kecamatan Geger, kabupaten Madiun sehingga arah kebijakan sekolah terhadap pembelajaran ini menjadi lebih baik.

Berdasarkan latar belakang masalah yang dikemukakan di atas maka penelitian ini bertujuan untuk mendeskripsikan bagaimana implemen tasi penanaman karakter positif siswa dalam pembelajaran seni budaya di SDN Jogodayuh 1, Kecamatan Geger, 
Kabupaten Madiun? dan juga memaparkan kendala yang ditemui di lapangan pada implementasi penanaman karakter positif siswa dalam pembelajaran seni budaya di SDN Jogodayuh 1, Kecamatan Geger, Kabupaten Madiun.

Secara harfiah, karakter memiliki arti kualitas mental atau moral, kekuatan moral, nama atau reputasi (Hornby dan Parnwell, dalam Hidayatullah, 2010:14). Karakter memiliki kualitas dan kekuatan mental atau moral, akhlak atau budi pekerti individu yang merupakan kepribadian khusus yang menjadi pendorong dan penggerak, serta dapat menjadi pembeda dengan individu yang lain. Menurut Kamus Lengkap Bahasa Indonesia, karakter memunyai pengertian sifat-sifat kejiwaan, akhlak atau budi pekerti yang menjadi ciri khas seseorang.

Menurut Ramli (dalam Narwanti, 2011:15), pendidikan karakter memiliki esensi dan makna yang sama dengan pendidikan moral dan pendidikan akhlak. Sudah jelas dari pernyataan tersebut bahwa tujuan dari pendidikan karakter adalah untuk membentuk pribadi anak, agar menjadi manusia yang baik, serta menjadi warga negara yang baik pula. Dari beberapa pengertian di atas dapat disimpulkan bahwa pendidikan karakter merupakan sebuah sistem yang berguna untuk membentuk watak, sifat, minat, serta kepribadian masing-masing orang berkaitan dengan hubungan antar makhluk sosial.

Seni budaya merupakan mata pelajaran yang memberikan kesempatan kepada siswa untuk terlibat dalam berbagai pengalaman apresiasi maupun pengalaman berkreasi untuk menghasilkan suatu produk berupa benda nyata yang bermanfaat langsung bagi kehidupan siswa. Dalam mata pelajaran seni budaya, siswa melakukan interaksi terhadap benda-benda produk kerajinan dan teknologi yang ada dilingkungan siswa, dan kemudian berkreasi terhadap benda- seni,benda produk kerajinan maupun produk teknologi secara sistematis, sehingga diperoleh pengalaman apresiatif dan pengalaman kreatif. Tujuan pembelajaran seni budaya adalah untuk meningkatkan sensitifitas,kemampuan mengapresiasi dan mengekspresikaan keindahan serta harmoni.

\section{B. Metode Penelitian}

Penelitian ini termasuk pada jenis penelitian kualitatif dengan pendekatan fenomenologis. Menurut Bogdan dan Taylor dalam Moleong (1975:5), metodologi kualitatif sebagai prosedur penelitian yang menghasilkan data deskriptif berupa kata-kata tertulis atau lisan dari orang-orang dan perilaku yang dapat diamati.

Objek penelitian ini adalah implementasi penanaman karakter positif dalam pembelajaran seni budaya di SDN Jogodayuh, Kecamatan Geger, Kabupaten Madiun sedangkan subjek 
penelitiannya adalah guru kelas tinggi dan siswa kelas tinggi SDN Jogodayuh 1, Kecamatan Geger, Kabupaten Madiun, sebab untuk siswa kelas rendah pembelajaran dilaksanakan secara tematis sehingga tidak hanya terfokus pada pembelajaran seni budaya.

Waktu penelitian ini adalah selama delapan bulan dengan asumsi bahwa proses semester di SD terjadi selama enam bulan sampai pada tahap evaluasi dan proses analisis serta pelaporan diberi waktu dua bulan.

Data dalam penelitian ini adalah (1) data perangkat pembelajaran yang dihasilkan oleh guru terkait dengan pembelajaran seni budaya di SDN Jogodayuh 1, Kecamatan Geger, kabupaten Madiun; (2) data keterlaksanaan penanaman karakter positif dalam pembelajaran seni budaya; (3) data tentang alat evaluasi yang dihasilkan oleh guru; (4) data tentang kendala pelaksanaan penanaman karakter positif dalam pembelajaran seni budaya.

Teknik dokumentasi, observasi langsung, maupun wawancara menuntut peneliti menjadi instrumen utama dalam penelitian ini. Dalam penelitian ini juga digunakan dua teknik triangulasi untuk memeriksa keabsahan data.

Analisis data yang digunakan untuk memperoleh simpulan penelitian dalam penelitian ini adalah (1) reduksi data dari hasil triangulasi data, (2) membandingkan data tidak tereduksi, dan (3) menarik kesimpulan dengan mengaitkan data tidak tereduksi.

\section{Hasil Dan Pembahasan \\ 1. Deskripsi Data}

Hasil penelitian pelaksanaan pembelajaran pertama terkait dengan pemeriksaan dokumen RPP dan dokumen alat evaluasi yang dikembangkan oleh guru kelas tinggi SDN Jogodayuh 1, Kecamatan Geger, Kabupaten Madiun dalam pembelajaran seni budaya. Dalam mengumpulkan dokumen tersebut peneliti dibantu oleh kepala sekolah selaku supervisor di sekolah yang diteliti. Selain itu untuk melihat detil dari dokumen dikembangkan istrumen cekc list sebagai berikut.

\section{a. Dokumentasi RPP yang Dikembangkan Guru}

Sebelum melaksanakan pembelajaran, guru terlebih dahulu membuat RPP. RPP yang dikembangkan kemudian diaplikasikan dalam kegiatan pembelajaran. Berikut ini hasil dokumentasi RPP yang dikembangkan oleh guru kelas tinggi SDN Jogodayuh 1, Kecamatan Geger, Kabupaten Madiun dalam pembelajaran seni budaya.

Berdasarkan data, dari segi format RPP, format yang digunakan oleh guru dalam membuat RPP sudah sesuai dengan KTSP dan sistematika penulisan RPP juga sudah mengikuti kaidah kelogisan dan keruntutan. Dari segi kebahasaan, guru telah menggunakan kalimat efektif dan kalimat yang mudah 
dipahami dalam menulis RPP. Dari segi isi, RPP sudah lengkap dan sudah sesuai dengan syarat RPP yang baik. Selain itu, isi RPP juga telah menggambarkan kegiatan pembelajaran yang akan dilakukan secara rinci. Terakhir, isi RPP telah menggambarkan prinsip pembelajaran tingkat satuan sesuai dengan Kurikulum Tingkat Satuan Pendidikan. Analisis tersebut menunjukkan bahwa dokumen RPP dan dokumen alat evaluasi yang dikembangkan oleh guru kelas tinggi SDN Jogodayuh 1, Kecamatan Geger, Kabupaten Madiun dalam pembelajaran seni budaya sudah sangat baik.

\section{b. Dokumen Evaluasi yang Dikembangkan Guru}

Dalam kegiatan pembelajaran, guru juga mengembangkan alat evaluasi. Alat evaluasi yang dikembangkan kemudian diaplikasikan dalam kegiatan pembelajaran. Berikut ini hasil dokumentasi alat evaluasi yang dikembangkan oleh guru kelas tinggi SDN Jogodayuh 1, Kecamatan Geger, Kabupaten Madiun dalam pembelajaran seni budaya.

Berdasarkan data, dari segi format alat evaluasi, teknik evaluasi yang digunakan oleh guru sudah bervariasi antara tes dan non tes, bentuk soal untuk tes yang dikembangkan oleh guru juga sudah bervariasi (kinerja, tulis), dan alat evaluasi yang dikembangkan sudah memuat petunjuk pengerjaan dan soal sesuai dengan bentuk evaluasi yang digunakan. Dari segi kebahasaan, alat evaluasi yang dikembangkan guru sudah menggunakan kalimat efektif dan sudah memperhatikan unsur EYD. Dari segi isi, alat evaluasi yang dikembangkan guru sudah sesuai dengan kompetensi yang diukur dan alat evaluasi yang dikembangkan juga sudah mengukur kemampuan siswa secara holistic. Dan dari segi kebobotan, guru menggunakan bobot evaluasi yang berbeda sesuai dengan ketercapaian materi ajar. Analisis tersebut menunjukkan bahwa dokumen alat evaluasi yang dikembangkan oleh guru kelas tinggi SDN Jogodayuh 1, Kecamatan Geger, Kabupaten Madiun dalam pembelajaran seni budaya sudah sangat baik.

\section{c. Proses pelaksanaan pembelajaran dengan observasi langsung}

Untukmengobservasi

keterlaksanaan pembelajaran di kelas peneliti menggunakan dua instrumen pendukung yaitu catatan lapangan dan lembar ceck list. Berdasarkan hasil observasi, kegiatan guru saat proses awal pembelajaran sudah sesuai dengan RPP yang dikembangkan. Pada apersepsi, guru telah mengingatkan materi yang lalu mengenai meronce. Selanjutnya guru memberi informasi tentang materi yaitu tentang cara membuat bunga dari sedotan. Guru juga memberikan informasi tujuan belajar yaitu siswa dapat terampil dalam membuat rangkaian bunga dari sedotan. 
Hasil observasi kegiatan guru saat inti menyatakan bahwa guru membagi siswa menjadi 4 kelompok, kemudian guru menunjukkan roncean bunga dari sedotan sedangkan iswa mengamati rangkaian bunga tersebut. Setelah mengamati, siswa mempraktekkan cara merangkai bunga dari sedotan. Secara bersamaan, siswa dan guru tanya jawab mengenai cara merangkai bunga. Terakhir, siswa mengerjakan tugasnya dan guru mengevaluasi hasil kerja siswa. Kegiatan guru saat akhir pembelajaran juga diobservasi. Hasilnya menunjukkan bahwa pada saat simpulan, guru dan siswa menyimpulkan materi. Pada saat refleksi, guru menanyakan kepada siswa mengenai materi yang belum dimengerti serta kesan-kesan selama pembelajaran dan pada langkah tindak lanjut, guru memberi tugas kepada siswa agar membuat roncean bunga dari sedotan dirumah dan hasilnya dikumpulkan minggu depan.

Analisis tersebut menunjukkan bahwa proses pembelajaran yang dilaksanakan telah sesuai dengan RPP yang dikembangkan sebelumnya oleh guru kelas tinggi SDN Jogodayuh 1, Kecamatan Geger, Kabupaten Madiun. Sejalan dengan hasil pengamatan secara langsung, hasil ceck list juga menunjukkan hasil yang tidak jauh berbeda. Berdasarkan hasil ceck list di atas, kegiatan guru saat proses awal pembelajaran sudah sesuai dengan RPP yang dikembangkan. Pada apersepsi, telah ada faktor pembiasaan, ada apersepsi berbasis pegetahuan awal siswa, dan sudah ada improvisasi yang relevan. Hasil ceck list kegiatan guru saat inti menyatakan bahwa guru telah melaksanakan langkah yang sesuai dengan detail dalam RPP, prosedur sudah sesuai dengan metode yang digunakan dan telah ada improvisasi yang relevan. Kegiatan guru saat akhir pembelajaran telah ada penutup, ada umpan balik, dan ada improvisasi yang relevan. Dari ketiga kegiatan di atas, guru juga telah melaksanakan pengelolaan waktu yang sesuai dengan RPP.

Berdasarkan analisis di atas, proses pembelajaran yang dilaksanakan telah sesuai dengan RPP yang dikembangkan sebelumnya oleh guru kelas tinggi SDN Jogodayuh 1, Kecamatan Geger, Kabupaten Madiun.

\section{d. Data kendala penanaman karakter positif dalam pembelajaran seni budaya di SDN Jogodayuh 1, Kecamatan Geger, Kabupaten \\ Madiun}

Penanaman karakter positif dalam pembelajaran seni budaya di SDN Jogodayuh 1, Kecamatan geger, Kabupaten Madiun juga menemui kendala. Berdasarkan data, kendala yang ditemui adalah pada saat implementasi pengelolaan kelas agar efektif dan efisien serta mengatasi siswa yang kurang terampil. Anak-anak saat pembelajaran seni sulit mengekspresikan lagu dengan benar khususnya lagu-lagu 
nasional dengan tepat. Kendala tersebut dpata diatasi dengan peran pihak sekolah untuk meningkatkan pembelajaran Seni budaya disekolah agar menarik dan bermakna serta mengasah ketrampilan siswa.

\section{Temuan Penelitian}

Dalam perencanaan pembelajaran yang dilakukan oleh guru dengan proses implementasi pelaksanaan pembelajaran seni budaya sesuai dan setiap kegiatan pendahuluan, inti dan penutup telah terlaksana dengan sistematis dan sinkron. Selain itu bahasa yang digunakan efektif dan mudah dipahami. Dengan pengunaan bahasa yang jelas dan tidak ambigu mampu memudahkan internalisasi materi pembelajaran oleh siswa. Isi rencana pelaksanaan pembelajaran yang lengkap dan rinci serta kegiatan penutup antara proses dengan yang terdapat di rencana pelaksanaan pembelajaran sinkron. Kemudian dalam pelaksanaan pembelajaran terdapat penggelolan waktu efektif.

\section{Implementasi Penanaman Karakter Positif Dalam Pembelajaran Seni Budaya SDN I Jogodayuh}

ImplementasiPenanaman

Karakter Positif Dalam Pembelajaran Seni Budaya SDN I Jogodayuh dilakukan berdasarkan dengan kegiatan pembelajaran di Rencana pelaksanaan pembelajaran dan pengamatan secara langsung pelaksanaan pembelajaran.

Seni budaya merupakan mata pelajaran yang memberikan kesempatan kepada siswa untuk terlibat dalam berbagai pengalaman apresiasi maupun pengalaman berkreasi untuk menghasilkan suatu produk berupa benda nyata yang bermanfaat langsung bagi kehidupan siswa. Dalam mata pelajaran seni budaya, siswa melakukan interaksi terhadap benda-benda produk kerajinan dan teknologi yang ada dilingkungan siswa, dan kemudian berkreasi terhadap benda - seni, benda produk kerajinan maupun produk teknologi secara sistematis, sehingga diperoleh pengalaman apresiatif dan pengalaman kreatif. Tujuan pembelajaran seni budaya adalah untuk meningkatkan sensitifitas,kemampuan mengapresiasi dan mengekspresikaan keindahan serta harmoni.

Mengenai manfaat belajar nilai-nilai mempelajari seni budaya diantaranya:

(1) memperdalam pengertian tentang rasa indah pada umumnya dan tentang kesenian pada khususnya, (2) memperluas pengetahuan unsur objektif dan subjektif yang berpengaruh atas kemampuan menikmati keindahan, (3) memperkokoh rasa cinta kepada kesenian dan kebudayaan bangsa pada umumnya serta mempertajam kemampuan mengapresiasi (menghargai) kesenian dan kebudayaan bangsa lain, dan dengan demikian mempererat hubungan antarbangsa, (4) memupuk kehalusan rasa dalam diri manusia, (5) memperdalam pengertian tentang 
hubungan kesenian dengan tata kehidupan, kebudayaan, dan perekonomian suatu masyarakat,

(6) memantabkan kemampuan menilai karya seni guna mengembangkan apresiasi seni di dalam masyarakat,

memantabkan kewaspadaan atas pengaruh negatif yang merusak mutu kesenian dan nilai-nilai kebudayaan kita, (8) memperkokoh keyakinan dalam masyarakat terhadap nilai kesusilaan, moralitas, perikemanusiaan dan ketuhanan,

(9) melatih diri untuk berdisiplin dalam cara berpikir dan mengatur pemikiran dengan sistematik, membangkitkan potensi untuk berfalsafah agar memperoleh kemudahan dalam menghadapi segala permasalahan, memberi wawasan yang luas dan bekal bagi kehidupan spiritual dan psikologis.

Di dalam kegiatan apresiasi dan kreasi seni budaya terkandung nilai ekspresi sebagai bentuk ungkapan yang bermakna. Nilai ekspresi dalam seni merupakan hasil pengolahan cipta, rasa, dan karsa. Dengan pendidikan seni melalui pengalaman estetik, siswa dapat menginternalisasi (meresapi, mengakarkan) nilai-nilai estetik yang berfungsi untuk melatih kepekaan rasa, kecerdasan intelektual, dan mengembangkan imajinasinya. Suatu pengalaman estetik tidak mungkin bisa dicapai tanpa melibatkan olah rasa (emosi, estetika), olah hati (karsa, etika), olah cipta (pikir, logika), dan olah raga (fisik, kinestetika terutama untuk seni tari).

Dalam pembelajaran di SDN I Jogodayuh terdapat aspek penanaman karakter kepada siswa yaitu melalui merangkai bunga dari sedotan. Dalam kegiatan pembelajaran merangkai bunga dari sedotan terdapat penanaman karakter sebagai berikut.

1) Kepedulian dan Empati, Rasa Bangga, serta Sikap Respek.

Ketiga karakter dasar anak ini dapat dikembangkan dalam kegiatan produksi bunga dari sedotan dengan membiasakan anak berperilaku menghargai ide dan hasil karya orang lain. Anak dibiasakan mengekspresikan kreasinya melalui proses merangkai bunga, guru memberikan bimbingan serta tidak melupakan pujian atas ide dan karya anak sebagai proses penguatan perilaku.

2) Kerjasama, Suka Menolong, dan Toleransi.

Ketiga moral dasar lainnya dibiasakan dalam aktivitas merangkai bunga dalam wujud saling membantu proses hingga menghasilkan hasil karya bunga yang diinginkan anak.

3) Mandiri dan Percaya Diri, Banyak Akal, serta Tanggung Jawab.

Ketiga moral dasar ini hanya dapat dibiasakan jika guru memberikan kepercayaan penuh pada anak untuk mewujudkan ide dan karyanya dalam wujud bunga dari sedotan. Guru tidak perlu terlalu banyak instruksi, tetapi lebih pada memfasilitasi kebutuhan praktek produksi bunga dari sedotan ini 
pada anak. Anak akan terbiasa mempertanggungjawabkan hasil kerja dan aktivitas setelahnya untuk membersihkan ruangan dari sisa merangkai bunga dari sedotan.

4) Sabar

Sabar merupakan karakter yang sangat dibutuhkan ketika anak merangkai bunga. Dalam kegiatan ini anak harus menyatukan beberapa bagian bunga menjadi satu rangkaian bunga siap digunakan. Proses tersebut menuntut adanya kesabaran anak dalam melakukannya sehingga dihasilkan bunga sedotan yang sesuai imajinasinya. Kemudian di kegiatan pembelajaran kedua di SDN I Jogodayuh terdapat aspek penanaman karakter kepada siswa yaitu melalui kegiatan menyanyikan lagu dengan ketepatan nada, temo dan penghayatan yang tepat terhadap makna lagu. Kegiatan pembelajaran tersebut terdapat penanaman karakter sebagai berikut:

5) Kepedulian dan Empati, Kerjasama, Adil, Suka Menolong, Sikap Respek, Tanggung Jawab, Rasa Bangga, serta Toleran.

Ketujuh sikap moral dasar sebagai karakter anak ini dapat dibiasakan dalam aktivitas menyanyikan lagu "Hymne Guru" dengan saling membantu agar dapat saling menyanyikan lagu denga nada, tempo dan intonasi yang tepat.

6) Berani, Kejujuran dan Integritas. Sikap berani dimulai dengan berani tampil, berani berbicara dan berpendapat, hingga berani menyanyikan lagu "Hymne Guru". Keberanian dibarengi dengan kejujuran dan intergritas akan melatih anak menempatkan diri sebagai individu yang berkarakter positif. Banyak contoh sikap karakter ini yang dapat diperankan dalam bernyanyi.

7) Keteguhan dan Komitmen, Percaya

Diri, dan Loyalitas.

Kemandirian dengan sendirinya akan melahirkan komitmen dan loyalitas terhadap lingkungan anak. Percaya diri dapat dikembangkan melalui penampilan menyanyikan lagu hymne guru. Hal ini akan melahirkan komitmen pada tugas dan tanggung jawabnya di kelas. Secara tidak sadar loyalitas pada aturan akan terbentuk dari pembiasaan disiplin yang diterapkan ketika anak bernyanyi.

8) Nasionalisme

Karakter ini dapat diajarkan pada siswa ketika menyanyikan lagu kebangsaan seperti "Hymne Guru". Pada saat siswa mengetahui jasa seorang guru dalam mencerdaskan anak bangsa, siswa akan merasa bangga dan menghargai jasa-jasa guru.

9) Ketelitian

Sikap teliti dapat ditanamkan pada siswa pada saat menemukan ketepatan nada, tempo dan makna yang terkandung di lagu "Hymne Guru". 
Pembentukan karakter dapat terbentuk dengan indikator siswa mengerti cara merangkai bunga dan menyanyikan lagu. Siswa cenderung akan meniru hal-hal yang dilihat dan didengarnya. Maka dari itu, dalam melakukan kegiatan ini perlu adanya peran aktif dari guru maupun orang tua untuk selalu mendampingi anak anak mereka dam mampu meniru serta mewujudkan karakter dan moral dari perilaku baik yang telah disampaikan.

\section{Kesimpulan}

Manfaat belajar nilai-nilai mempelajari seni budaya di sekolah dasar diantaranya: (1) memperdalam pengertian tentang rasa indah pada umumnya dan tentang kesenian pada khususnya,

(2) memperluas pengetahuan unsur objektif dan subjektif yang berpengaruh atas kemampuan menikmati keindahan,

memperkokoh rasa cinta kepada kesenian dan kebudayaan bangsa pada umumnya serta mempertajam kemampuan mengapresiasi (menghargai) kesenian dan kebudayaan bangsa lain, dan dengan demikian mempererat hubungan antarbangsa, memupuk kehalusan rasa dalam diri manusia, (5) memperdalam pengertian tentang hubungan kesenian dengan tata kehidupan, kebudayaan, dan perekonomian suatu masyarakat, (6) memantabkan kemampuan menilai karya seni guna mengembangkan apresiasi seni di dalam masyarakat, (7) memantabkan kewaspadaan atas pengaruh negatif yang merusak mutu kesenian dan nilai-nilai kebudayaan kita, (8) memperkokoh keyakinan dalam masyarakat terhadap nilai kesusilaan, moralitas, perikemanusiaan dan ketuhanan, (9) melatih diri untuk berdisiplin dalam cara berpikir dan mengatur pemikiran dengan sistematik, membangkitkan potensi untuk berfalsafah agar memperoleh kemudahan dalam menghadapi segala permasalahan, memberi wawasan yang luas dan bekal bagi kehidupan spiritual dan psikologis.

\section{Referensi}

Arikunto, Suharsimi. 2012. Prosedur Penelitian Suatu pendekatan Praktek. Jakarta: Rineka Cipta

Djohan, 2009, Psikologi Musik, Yogyakarta: Penerbit Best Publiser

Gafur Abdul.2007. Bahan Diklat Profesi Guru Sertifikasi Guru Rayon II

DIY Jateng. Buku B 2.4. Pengembangan Rencana Pelaksanaan Pembelajaran (RPP)

Hugh, M.Miller,1958, Introduction to Music, a Guide to Good listening

Jazuli, 2008. Paradigma Konstektual Pendidikan Seni. Surabaya: Unesa University Press

Kesuma, Dharma, Cepi Triatna, Johar Permana. 2011. Pendidikan Karakter Kajian Teori dan Praktik 
di Sekolah. Bandung:

Remaja Rosdakarya.

Majid, Abdul. 2008. Perencanaan Pembelajaran

Mengembangkan Standar Kompetensi Guru. Bandung: Rosda

Moleong, Lexy J. 2012. Metodologi Penelitian Kualitatif. Rosdakarya

Bandung:

Muslich, Masnur. 2011. Pendidikan Karakter: Menjawab Tantangan Krisis
Multidimensional. Jakarta: Bumi Aksara.

Narwanti, Sri. 2011. Pendidikan Karakter. Yogyakarta: Familia.

Pekerti, Widia. 2002. Pendidikan Seni Musik-Tari/Drama. Jakarta: UT

Sa'ud, Saefudin. 2008. Inovasi Pendidikan. Bandung: Alfabeta

Suka Hardjana,2004, Musik Antara Kritik dan Apresiasi, Jakarta: terjemahan Triyono Bramantyo P.S (New Mexico \& Nobel) 
